\title{
How to measure the e-commerce development index of China's iron and steel industry?
}

\author{
Juan Huang ${ }^{1,2, a}$, Chuanmin Shuai ${ }^{2, b}$ and Weipei Yao $^{2, c}$ \\ ${ }^{1}$ School of Mathematics and Physics, China University of Geosciences, Wuhan 430074, China; \\ ${ }^{2}$ School of Economics and Management, China University of Geosciences, Wuhan 430074, China. \\ a hjrosamm@163.com, ${ }^{\text {b }}$ shuaicm@cug.edu.cn, c yaoweipei1991@sina.com
}

Keywords: iron and steel industry; e-commerce; analytic hierarchy process (AHP)

\begin{abstract}
The development of e-commerce has a significant influence on international trade, and the application of e-commerce in the iron and steel industry is becoming more and more popular. This paper has built an e-commerce development index of China's iron and steel industry based on data from 2006 to 2014. The results indicate that: (1) the development level of e-commerce has been increasing year by year. (2) the e-commerce development level of China's iron and steel industry has been rising unceasingly, which has been greatly influenced by the basic environment of e-commerce. Finally, this paper has proposed corresponding policy recommendations based on the above findings.
\end{abstract}

\section{Introduction}

Iron and steel industry is the backbone and a basic industry of the national economy and people's livelihood. It has played an irreplaceable role in the process of China's industrial modernization and has the pivotal status in the whole national economy. The $+"$ initiative of the Chinese government will play a positive role in promoting and encouraging e-commerce development. In the context of rapid development of the e-commerce market, iron and steel enterprises' e-commerce is adapt to the needs of market competition. As a pillar industry, how about the present situation of e-commerce development of the iron and steel industry in China? In this paper, we made an attempt to measure the level of e-commerce development of the iron and steel industry in China from 2006 to 2014.

\section{Literature review}

For estimating the e-commerce level, scholars have set their index systems with different measurement and standards. The International Statistical Information Center (CINIC) of China's National Bureau of Statistics (2000) proposed the CII China's e-commerce index, which measures e-commerce development from nine dimensions [1]. OECD (2001) put forward the index of enterprise e-commerce measurement as follows: enterprises with computers, enterprises with Internet connections, enterprises with their own websites, enterprises' plans to do business on the Internet, and enterprises with the Internet to accept orders etc [2]. APEC (2003) evaluated the development of e-commerce from six dimensions: basic architecture and technology, necessary service connections, the level and type of Internet use, the perceived level of e-commerce, skills and human resources, digital economic situation [3].

Nie Qiuyun (2013) used a Cobb-Douglas function model to analyze the impact of e-commerce on China's service industry where e-commerce index is defined and measured by transaction level index, infrastructure index, human capital index, development potential index and network prosperity index [4]. Li Shixian (2014) quantitatively analyzed the impact of e-commerce development on trade, and selected five dimensions including infrastructure, industry technology, application consumption, knowledge support and development effect to measure the e-commerce development index [5].Among the previous research about the impact of e-commerce development 
on trade, most scholars have elaborated the impact of e-commerce on international trade qualitatively, they accounted that e-commerce changes the traditional export trade in the way of trading, trade processes, marketing methods and trade costs etc (Ma Jian 2008; Weng Haijie, 2010; Li Junyang, 2014) [6-8].

\section{Data and methodology}

\subsection{Index system}

Based on the previous research on the measurement of e-commerce level and the availability of data, this paper summarized the following index system to measure the e-commerce development index of the iron and steel industry (Table 1).

Table 1 Evaluation index system of e-commerce development level of China's iron and steel industry

\begin{tabular}{|c|c|c|}
\hline Target layer & Criterion layer & Indicator layer \\
\hline \multirow{7}{*}{$\begin{array}{l}\text { E-commerce development index of iron } \\
\text { and steel industry }\end{array}$} & \multirow{3}{*}{ Basic environment } & Year-end No. of computers in use \\
\hline & & Year-end No. of sites owned \\
\hline & & No. of e-commerce employees \\
\hline & \multirow{2}{*}{ Transaction scale } & E-commerce purchases \\
\hline & & E-commerce sales \\
\hline & \multirow{2}{*}{$\begin{array}{l}\text { National economic } \\
\text { impact }\end{array}$} & $\begin{array}{c}\text { \% of e-commerce transactions, as against } \\
\text { total industry output }\end{array}$ \\
\hline & & $\begin{array}{l}\% \text { of e-commerce transactions, as against } \\
\text { GDP }\end{array}$ \\
\hline
\end{tabular}

Data source: built by the authors for this research.

\subsection{Empirical analyses}

In this paper, we adopted the analytic hierarchy process (AHP) to determine the weights of the ecommerce development index for China's iron and steel industry. Firstly, according to the experts scoring of the questionnaire, we calculated the weights of each indicator by using the ya AHP software. Then, we used formula (1) to normalize the indicator layer data, and calculated the standardized data for each indicator. Finally, we calculated the e-commerce development index for the iron and steel industry for each year from the standardized data using equation (2).

$$
X_{i j}^{\prime}=\frac{X_{i j}}{\operatorname{Max}_{i}},
$$

where, $X_{i j}$ denotes the raw data, $\operatorname{Max} X_{i}$ represents the maximum value of i-th indicator in the time series, $X_{i j}^{\prime}$ indicates the dimensionless value of the raw data, $i$ is from 1 to $7, j$ is from 2006 to 2014.

$$
P_{j}=\sum_{i=1}^{7}\left(X_{i j}^{\prime} \cdot \omega_{i}\right)
$$

where, $P_{j}$ is the value of the e-commerce development index in the $j$-th year calculated in this paper. $\omega_{i}$ is the weight of the $i$-th indicator which obtained according to analytic hierarchy process.

According to the above method, the weights of each indicator are calculated and shown in Table 2, and the e-commerce development index of China's iron and steel industry from 2006 to 2014 is measured and shown in Table 3. 
Table 2 Evaluation indicator weights of e-commerce development level of China's iron and steel industry

\begin{tabular}{cccccccc}
\hline & \multicolumn{3}{c}{ Basic environment } & \multicolumn{2}{c}{ Transaction scale } & \multicolumn{2}{c}{ National economic impact } \\
\cline { 2 - 8 } Indicators & $\begin{array}{c}\text { Year-end } \\
\text { No. of } \\
\text { computers }\end{array}$ & $\begin{array}{c}\text { Year- } \\
\text { end No. } \\
\text { of sites } \\
\text { owned }\end{array}$ & $\begin{array}{c}\text { No. EC } \\
\text { employees }\end{array}$ & $\begin{array}{c}\text { EC } \\
\text { purchases }\end{array}$ & $\begin{array}{c}\text { EC } \\
\text { sales }\end{array}$ & $\begin{array}{c}\text { purchases \% } \\
\text { in total } \\
\text { industry } \\
\text { output }\end{array}$ & $\begin{array}{c}\text { EC } \\
\text { transactions \% } \\
\text { in GDP }\end{array}$ \\
\hline Weights & 0.2535 & 0.3403 & 0.0600 & 0.0508 & 0.0897 & 0.1715 & 0.0337 \\
\hline
\end{tabular}

Data source: calculated by the author from the results derived from this paper. EC represents ecommerce.

Table 3 E-commerce development index of China's iron and steel industry (2006-2014)

\begin{tabular}{cccccccccc}
\hline Year & 2006 & 2007 & 2008 & 2009 & 2010 & 2011 & 2012 & 2013 & 2014 \\
\hline Index & 0.2506 & 0.2628 & 0.2740 & 0.3379 & 0.4065 & 0.5333 & 0.6499 & 0.7733 & 0.8039 \\
\hline
\end{tabular}

Data source: calculated by the authors from the results obtained.

Table 2 shows that the weights of the e-commerce development index for China's iron and steel industry on the three dimensions (basic environment, transaction scale and National economic impact) are 0.65, 0.14, 0.21 respectively, indicating that e-commerce infrastructure has a significant influence on the e-commerce development level. From Table 3, we can see that China's iron and steel industry e-commerce index from 2006 to 2014 shows a year-by-year trend, indicating that the e-commerce development level is constantly improving.

\section{Conclusions and recommendations}

\subsection{Conclusions}

Based on the above analysis, we draw the following conclusions: (1) the development level of ecommerce has been increasing year by year. The index of e-commerce development has increased from 0.2506 in 2006 to 0.8039 in 2014, signifying that China's iron and steel industry is adapting to the development of market and the future of e-commerce. (2) The weights of China's iron and steel industry e-commerce development index on the three dimensions -- basic environment, transactions scale, and national economy are $0.65,0.14,0.21$ respectively, indicating that basic environment has a major impact on the development of e-commerce of China's iron and steel industry.

\subsection{Policy recommendations}

Strengthen the construction of e-commerce infrastructure for e-commerce in China, to accelerate the development of e-commerce of the iron and steel industry.

(1) Under the promotion of national policies and market development trend, the development of the iron and steel industry e-commerce is to meet the needs of market competition, we should actively promote the development of the iron-and-steel industry e-commerce.

(2) On the one hand, the Chinese government should increase financial investment, develop telecommunications infrastructure, and ensure the security, stability and rapidity of network communication system, thus facilitating the e-commerce infrastructure environment. On the other hand, it should establish and continuously improve the e-commerce service platform, thereby enhancing the iron and steel enterprises for better applications of e-commerce infrastructure. 


\section{Acknowledgments}

This work was supported in part by the fund project: China University of Geosciences (Wuhan) digital business management research center open fund and Ministry of education philosophy and social science research major research project: " China's mineral resources strategy research under the background of economic globalization " (ID: 12JZD034).

\section{References}

[1]. China National Bureau of Statistics, International Information and Statistics Center. (2000). CII released China's e-commerce index report. China Internet Weekly. 31.

[2]. OECD. (2001). Measuring ICT usage and electronic commerce in enterprises: proposal for a model questionnaire on ICT usage. DSTI/ICCP/IIS, Paris.

[3]. Recommendation, Council, and Council Directive. (2003). Commission of the European communities. Proposal for a council recommendation on cancer screening 93.

[4]. Nie, Q.Y. (2013). Electronic commerce development level measurement and the empirical research of its impact on China's service industry. PhD thesis. Yunnan University of Finance and Economics, China.

[5]. Li, S. X. (2014). Research on the impact of e-commerce development on China's international trade. Phd thesis. Zhejiang University, China.

[6]. Ma, J. (2008). Research on the impact of e-commerce on international trade and countermeasures. Journal of Northern Economy. 13:33-34.

[7]. Weng, H. J. (2010). Research on the impact of e-commerce on international trade and countermeasures. Guide to Business. 2:191-192.

[8]. Li, J. Y. (2014). The impact mechanism of electronic commerce on the development of trade. Journal of Business Economics. 11:5-11. 